\title{
Investigation of Oral Candida Albicans Colonization in Patients Treated with Rapid Maxillary Expansion
}

\author{
Hızlı Maksiller Genişletme ile Tedavi Edilen Hastalarda Oral \\ Candida Albicans Kolonizasyonunun Araştırılması
}

Fundagül Bilgiç, Özlem Akıncı Sözer

Mustafa Kemal University Faculty of Dentistry, Department of Orthodontics, Hatay, Turkey

Keywords

Candida albicans, palatal expansion, orthodontic appliances

Anahtar Kelimeler

Candida albicans, palatal ekspansiyon, ortodontik apareyler

Received/Geliş Tarihi : 05.06.2017

Accepted/Kabul Tarihi : 10.08.2017

doi:10.4274/meandros. 18291

Address for Correspondence/Yazışma Adresi: Fundagül Bilgiç MD,

Mustafa Kemal University Faculty of Dentistry, Department of Orthodontics, Hatay, Turkey E-mail : fundagulbilgic@hotmail.com

ORCID ID: orcid.org/0000-0001-9008-2297

(C) Meandros Medical and Dental Journal, Published by Galenos Publishing House.

This is article distributed under the terms of the Creative Commons Attribution NonCommercial 4.0

International Licence (CC BY-NC 4.0).

\section{Abstract}

Objective: The purpose of this study was to investigate Candida albicans colonies in the oral microflora of patients treated with rapid maxillary expansion (RME).

Materials and Methods: Totally 54 male and female subjects, including 27 using bonded rapid maxillary expander and 27 patients without orthodontic treatment, were entered in the present study. The study group consisted of 27 patients (14 females and 13 males) suffering from both maxillary constriction and posterior cross-bite. Patients treated with a rigid acrylic, bonded rapid maxillary expander were evaluated two times using oral rinses: one at baseline (T0) and 2 after palatal spreading out (T1). The data were analyzed using a chi-square test and a Fisher's exact test.

Results: After the use of RME, no significant changes were found between the data showing C. albicans colonies at T0 and at T1 $(p=1.964)$.

Conclusion: Our data suggest that the RME therapy and appliance did not cause a significant change in oral C. albicans colonization.

Öz

Amaç: Bu çalışmanın amacı rapid maksiller ekspansiyon (RME) ile ağız mikroflorasındaki Candida albicans kolonizasyonunda, değişiklik meydana gelip gelmediğini saptamaktır.

Gereç ve Yöntemler: Çalışmamıza dahil edilen 54 hastadan, 27'si RME ile tedavi edilirken, geri kalan 27 hastaya ortodontik tedavi uygulanmamıştır. Maksiller darlık ve posterior cross-bite şikayeti bulunan 27 hasta (14 kız, 13 erkek) çalışma grubunu oluşturmaktadır. Maksiller genişletme amacı ile akrilik destekli sabit hızlı maksiller ekspansiyon aygıtı uygulanan çalışma grubu hastalarından, tedavi başlangıcında (T0) ve RME tedavisinin 1. ayında (T1) alınan oral yıkama sıvı örnekleri incelendi. Kontrol grubuna ortodontik tedavi uygulanmamıştır. Elde edilen veriler, ki-kare ve Fisher'in kesin ki-kare testi ile analiz edildi.

Bulgular: RME aygıtı ile palatal genişletme elde edildikten sonra, T0 ve T1 zaman aralıklarında elde edilen C. albicans varlığını gösteren veriler arasında istatistiksel açıdan anlamlı bir fark olmadığı saptanmıştır $(p=1,964)$.

Sonuç: Çalışmamızın sonucunda, RME aygıtının ve tedavi sonunda elde edilen palatal genişletmenin, hastaların oral C. albicans kolonizasyonunda anlamlı bir değişikliğe sebep olmadığını saptadık. 


\section{Introduction}

Aerobic and facultative anaerobic bacteria are primarily present on the surface of mucosal membranes. Oral bacterial species are detected on tooth surfaces, in the saliva, on the surface of the tongue, and in the tonsillar crypt (1). Aerobes and facultative anaerobes are found in large quantities in normal oropharyngeal flora and are the most common cause of upper respiratory infections (2). In addition to these bacteria, fungi such as Candida albicans may also colonize in the oral cavity (3).

Opportunistic bacteria and fungi, such as $C$. albicans, are usually found more frequently in patients with diminished immune responses. These organisms, which are correlated with periodontal diseases, can leads to systemic infections in patients with immunodeficiency diseases by aspiration from the mouth into the respiratory system (4-8). Inadequate oral care and periodontal diseases may support oropharyngeal colonization by existing respiratory system pathogens (4).

Conditions that cause mouth breathing particularly occur in childhood. Typical features of mouthbreathing individuals are a narrow and deep upper jaw that is constricted in the transverse direction, resulting in increased resistance to airflow through the nasal passages. In such orthodontic cases, rapid maxillary expansion (RME) is preferred for treatment (3). In orthodontic clinics, palatal expanders, common fixed appliances used in children and adults, are used to expand the narrow maxilla or to correct skeletal posterior cross-bites $(9,10)$. The primary purpose of RME devices is to obtain the lateral expansion force by the movements of the basal maxillary bone (3). The Haas appliance is commonly used for this purpose; it consists of acrylic resin components and is kept in the mouth for approximately four months (11).

Most appliances used for orthodontic treatment cause insufficient oral hygiene, which may alter the composition and amount of patients' oral microbiota. Studies have shown a direct correlation between biofilm accumulation, enamel demineralization, and even caries lesions with the use of orthodontic bands, brackets, and other devices (12-16). Biofilm formation and the fixation of primary bacterial colonization begins immediately after the placement of orthodontic appliances (17). Clinically, when the
RME is removed from the mouth, a thick biofilm layer can be observed under the acrylic component (11).

Kitada et al. (18) found that opportunistic bacteria and fungi are more commonly isolated in the oral cavity of orthodontic patients. Diamanti-Kipioti et al. (19) found that some types of periodontopathic bacteria significantly increased after the orthodontic bands were attached. Naranjo et al. (20) determined that the placement of brackets affected plaque accumulation and major periodontopathic bacterial colonization. One study determined that orthodontic magnetic brackets affected oral microbial flora and significantly stimulated the development of $C$. albicans within the first 24 hours (21). The aim of this study is to evaluate changes in the frequency of oral C. albicans in patients treated with RME.

\section{Materials and Methods}

This report was approved by the Mustafa Kemal University Tayfur Ata Sökmen Medical Faculty Clinical Research Ethics Committee (application number 26/05/2014/92). Fifty-four participants were included in the study and control groups and were selected from patients who applied to our clinic for orthodontic treatment. The study group consisting of 27 patients (13 males, 14 females, and mean age $14.3+2.17$ years) required RME for unilateral or bilateral cross-bite and orthodontic treatment. Exclusion criteria were nasal allergic conditions, airway obstruction, or periodontal disease. The patients received no antibiotic treatment or pharmacological therapy during the six months preceding the start of the treatment and had no systemic, oral mucosal or periodontal disease. Orthodontic treatment was not applied to the patients in the control group (12 males, 15 females, and mean age $13.3+1.17$ years) during the period when we collected the sample (Table 1). Before the placement of the RME appliances in the study group, oral hygiene training was given to the patients to manage bacterial plaque. The appliances were then cemented to the

\begin{tabular}{|l|l|l|}
\hline \multicolumn{3}{|l|}{ Table 1. Age distribution of the study patients } \\
\hline Groups & $\mathbf{n}$ & $\begin{array}{l}\text { Age } \\
\text { Mean } \pm \text { SD }\end{array}$ \\
\hline Study group & 27 & $14.3 \pm 2.17$ \\
\hline Control group & 27 & $13.3 \pm 1.82$ \\
\hline SD: Standard deviation & \\
\hline
\end{tabular}


patients' maxillary teeth, and the expansion screw was turned twice per day ( 1 turn $=0.25 \mathrm{~mm}$ ) until the required expansion was achieved (Figure 1).

Patients were instructed to rinse their mouths with $10 \mathrm{~mL}$ phosphate buffered saline (PBS) for $60 \mathrm{~s}$ before inserting the appliances (TO) and 30 days post-insertion (T1). Patients in the control group were also asked to rinse their mouth with $10 \mathrm{~mL}$ of PBS. The oral rinse samples were then expectorated back into a universal container, concentrated by centrifugation at 17.000 $\mathrm{g}$ for $10 \mathrm{~min}$, and the bottom plate was resuspended in PBS. Post-suspension samples were inoculated on to chloramphenicol Sabouraud dextrose agar (Merck, Germany) and incubated for 48 hours at $37^{\circ} \mathrm{C}$. Candida species were identified by the morphological structure of the colonies, the appearance of Gram strains, and germ tube formation. Positive germ tube test was identified as $C$. albicans.

\section{Statistical Analysis}

The data were analyzed using SPSS 16.0 (SPSS Benelux, Gorinchem, The Netherlands) computer software. A chi-square test was used to evaluate statistical differences between variables. A Fisher's exact test was used if the frequencies were less than $5-\mathrm{Hz}(\mathrm{p}<0.05$ in all analyses).

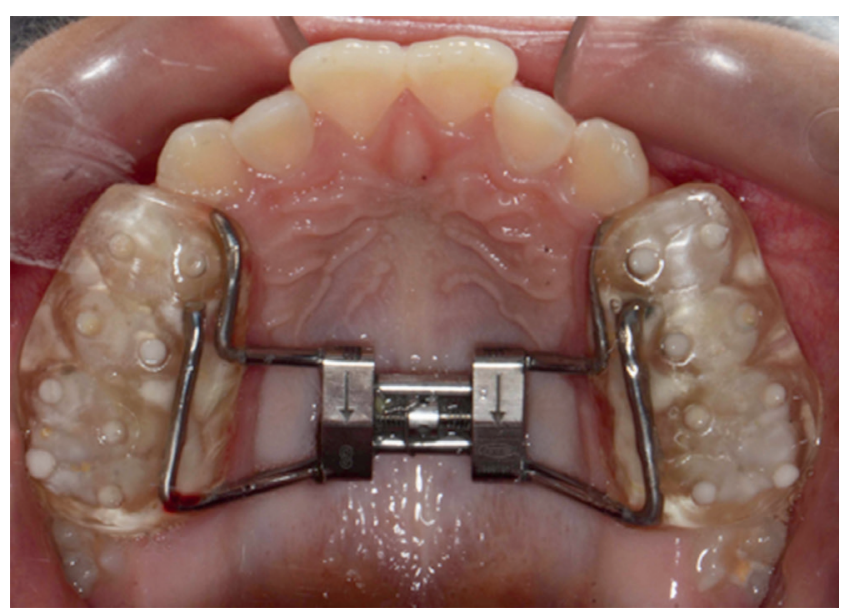

Figure 1. Rapid palatal expander appliance was used in the study group

\begin{tabular}{|c|c|c|c|c|}
\hline \multirow[b]{2}{*}{ Variable } & \multicolumn{4}{|c|}{ Time of assessment share, \% } \\
\hline & TO & $\mathrm{T} 1$ & Z & $\mathrm{P}^{*}$ \\
\hline Candida albicans & 3а (11.1\%) & 7a (25.9\%) & 0.293 & $1.964^{a}$ \\
\hline
\end{tabular}

\section{Results}

The change in the frequency of $C$. albicans at time intervals T0 and T1 is shown in Table 2. There was no statistically significant difference in the frequency of $C$. albicans among the study and control groups $(p=0.639)$. C. albicans was detected in three patients in the study group (11\%) at T0 and in seven patients in the study group (25\%) at T1, but this difference was not statistically significant $(p=1.964)$.

\section{Discussion}

RME is used in the orthodontic treatment of transverse maxillary deficiency (22). Improvement in respiratory function is achieved with RME therapy (23). Cazzolla et al. (3) found that oral pharyngeal pathogenic microflora was reduced in mouth breathers after RME treatment. The researchers (3) observed that the amount of $C$. albicans decreased until palatal expansion was achieved and then increased again at the end of the RME treatment. In our study, we investigated the quantitative assessment of the number of $C$. albicans in the oral cavity before treatment (T0) and after the first month (T1) of palatal expansion treatment.

As the method of oral rinsing is one of the most sensitive methods for evaluating oral yeast, we requested patients rinse their mouths with PBS to evaluate $C$. albicans colonization (24). Different solid culture media have been used in different studies to detect mutants. In our study, we used Sabouraud dextrose agar containing chloramphenicol, which is one of the most commonly used methods for determining the frequency of $C$. albicans (25).

The acrylic structure of the dental-mucussupported Haas expander appliance differentiates it from the Hyrax expansion appliance. Pithon et al. (11) found that the amount of microorganisms significantly increased in patients treated with the Haas and Hyrax palatal expanders, but the numbers of Streptococcus mutans and $C$. albicans were higher in the individuals using Haas appliances compared to those using the Hyrax appliance.

Khanpayeh et al. (26) observed that fixed orthodontic appliances did affect the oral mycological flora and changed individuals from being non-carriers of Candida species to being carriers. Fixed functional devices may cause a decrease in the local defense 
mechanism of oral mucosal cells. The adhesion of Candida to different dental surfaces can also affect colony formation during treatment. There is also a relationship between Candida and patient resistance to illness. The increase in the Candida population may cause a temporary weakness in the body resistance during the adaptive phase following the placement of the appliances and may be associated with the amount of plaque and microbes in the oral cavity of patients shortly after placement of the orthodontic appliances (27).

In a study of patients using removable and fixed orthodontic appliances, Candida density was found to be higher in the saliva samples of patients treated with fixed orthodontics. The main reason for the increase in inflammation and dental plaque is the existence of new retentive areas that may disrupt oral health $(20,28)$.

In contrast, Addy et al. (29) reported that fixed orthodontic treatment did not have a significant effect on oral Candida prevalence. Odeh et al. (30) also argued that fixed orthodontic appliances did not increase Candida colonization during the first four months of their study period. We found that there was no significant change in the amount of $C$. albicans during the first month in patients who used the RME appliances. Our results are consistent with the findings of other researchers.

Kitada et al. (18) found that the frequency of opportunistic bacteria and fungi in the oral cavity of orthodontic patients was higher than in those who did not receive orthodontic treatment. Opportunistic bacteria and fungi are frequently found at higher frequencies in patients with immunodeficiency disorders and the elderly, and the appliances used in orthodontic treatment may cause an oral environment where opportunistic organisms can develop and live. The application of orthodontic appliances makes tooth cleaning more difficult. The isolation frequencies of organisms differ significantly between patients receiving orthodontic treatment and those not receiving orthodontic treatment. If the immune system is weakened by the orthodontic appliance, special precautions should be taken to prevent diseases that may arise due to the increase in opportunistic bacteria and fungi. Researchers recommend that orthodontic appliances should not be used in immunocompromised individuals (18).
Naranjo et al. (20) stated that brackets affect plaque accumulation and colonization by superinfected bacteria, leading to more inflammation in the gingival tissues. Kitada et al. (18) found a high detection frequency of opportunistic bacteria and fungi during orthodontic treatment. Therefore, it may be necessary to employ special hygiene care of the oral cavity to prevent periodontal diseases and systemic diseases that suppress immunity.

Some factors, such as the sample size, were not statistically significant. The limited observation period and the chosen method, which did not have the sensitivity to detect low-intensity C. albicans, may affect the results. C. albicans isolated from the oral cavity and other Candida species may not cause clinical candidiasis if there are no lesions. In addition, the pathogenicity of $C$. albicans may vary depending on the number of organisms present (31). We evaluated the samples received from the patients at the beginning of the treatment and at the end of the first month of expansion to evaluate the effects of expansion with the RME on C. albicans frequency. Future studies in which the number of samples is increased and a longer observation period is employed will be useful in obtaining more accurate results.

\section{Conclusion}

This study revealed that the acrylic bonded RME appliance did not cause a significant change in the frequency of $C$. albicans.

\section{Ethics}

Ethics Committee Approval: This report was approved by the Mustafa Kemal University Tayfur Ata Sökmen Medical Faculty Clinical Research Ethics Committee (application number: 26/05/2014/92).

Informed Consent: Patients selected for our study were filled informed consent.

Peer-review: Externally peer-reviewed.

\section{Authorship Contributions}

Surgical and Medical Practices: F.B., Ö.A.S., Concept: F.B., Ö.A.S., Design: F.B., Ö.A.S., Data Collection or Processing: F.B., Analysis or Interpretation: F.B., Literature Search: F.B., Writing: F.B.

Conflict of Interest: No conflict of interest was declared by the authors.

Financial Disclosure: The authors declared that this study received no financial support. 


\section{References}

1. Sutter VL. Anaerobes as normal oral flora. Rev Infect Dis 1984; 6(Suppl 1): S62-6.

2. Brook I. Anaerobic bacteria in upper respiratory tract and other head and neck infections. Ann Otol Rhinol Laryngol 2002; 111: 430-40.

3. Cazzolla AP, Campisi G, Lacaita GM, Cuccia MA, Ripa A, Testa NF, et al. Changes in pharyngeal aerobic microflora in oral breathers after palatal rapid expansion. BMC Oral Health 2006; 6: 2 .

4. Scannapieco FA, Mylotte JM. Relationships between periodontal disease and bacterial pneumonia. J Periodontol 1996; 67(10 Suppl): 1114-22.

5. Senpuku H, Sogame A, Inoshita E, Tsuha Y, Miyazaki H, Hanada $\mathrm{N}$. Systemic diseases in association with microbial species in oral biofilm from elderly requiring care. Gerontology 2003; 49: 301-9.

6. Slots J, Feik D, Rams TE. Prevalence and antimicrobial susceptibility of Enterobacteriaceae, Pseudomonadaceae and Acinetobacter in human periodontitis. Oral Microbiol Immunol 1990; 5: 149-54.

7. Slots J, Rams TE, Listgarten MA. Yeasts, enteric rods and pseudomonads in the subgingival flora of severe adult periodontitis. Oral Microbiol Immunol 1988; 3: 47-52.

8. Valenti WM, Trudell RG, Bentley DW. Factors predisposing to oropharyngeal colonization with gram-negative bacilli in the aged. N Engl J Med 1978; 298: 1108-11.

9. Kiliç $\mathrm{N}$, Oktay $\mathrm{H}$. Effects of rapid maxillary expansion on nasal breathing and some naso-respiratory and breathing problems in growing children: a literature review. Int J Pediatr Otorhinolaryngol 2008; 72: 1595-601.

10. Ren Y. Rapid maxillary expansion treatment could produce longterm dental arch changes. Evid Based Dent 2005; 6: 93-4.

11. Pithon MM, Santos RLd, Alviano WS, Ruellas ACdO, Araújo MTdS. Quantitative assessment of $S$. mutans and C. albicans in patients with Haas and Hyrax expanders. Dental Press J Orthod 2012; 17: $1-6$.

12. Huser MC, Baehni PC, Lang R. Effects of orthodontic bands on microbiologic and clinical parameters. Am J Orthod Dentofacial Orthop 1990; 97: 213-8.

13. Sukontapatipark W, El-Agroudi MA, Selliseth NJ, Thunold K, Selvig KA. Bacterial colonization associated with fixed orthodontic appliances. A scanning electron microscopy study. Eur J Orthod 2001; 23: 475-84.

14. Auschill TM, Hein N, Hellwig E, Follo M, Sculean A, Arweiler NB. Effect of two antimicrobial agents on early in situ biofilm formation. J Clin Periodontol 2005; 32: 147-52.

15. Oliveira LB, Sheiham A, Bönecker M. Exploring the association of dental caries with social factors and nutritional status in Brazilian preschool children. Eur J Oral Sci 2008; 116: 37-43.

16. Percy MS. Oral health of adolescents--it's more than dental caries. MCN Am J Matern Child Nurs 2008; 33: 26-31.

17. Balenseifen JW, Madonia J. Study of dental plaque in orthodontic patients. J Dent Res 1970; 49: 320-4.
18. Kitada K, De Toledo A, Oho T. Increase in detectable opportunistic bacteria in the oral cavity of orthodontic patients. Int J Dent Hyg 2009; 7: 121-5.

19. Diamanti-Kipioti A, Gusberti FA, Lang NP. Clinical and microbiological effects of fixed orthodontic appliances. J Clin Periodontol 1987; 14: 326-33.

20. Naranjo AA, Triviño $M L$, Jaramillo A, Betancourth $M$, Botero JE. Changes in the subgingival microbiota and periodontal parameters before and 3 months after bracket placement. Am J Orthod Dentofacial Orthop 2006; 130: 275.

21. Staffolani N, Cervini M, Giannoni C, Guerra M, Pugliese M, D'Alò $F$, et al. The effect of orthodontic magnets on the oral microbial flora. Minerva Stomatol 1991; 40: 483-6.

22. Tecco S, Festa F, Tete S, Longhi V, D'Attilio M. Changes in head posture after rapid maxillary expansion in mouth-breathing girls: a controlled study. Angle Orthod 2005; 75: 171-6.

23. Basciftci FA, Mutlu N, Karaman Al, Malkoc S, Küçükkolbasi H. Does the timing and method of rapid maxillary expansion have an effect on the changes in nasal dimensions? Angle Orthod 2002; 72: 118-23.

24. Samaranayake LP, MacFarlane TW, Lamey PJ, Ferguson MM. A comparison of oral rinse and imprint sampling techniques for the detection of yeast, coliform and Staphylococcus aureus carriage in the oral cavity. J Oral Pathol 1986; 15: 386-8.

25. Furlaneto-Maia L, Specian AF, Bizerra FC, de Oliveira MT, Furlaneto MC. In vitro evaluation of putative virulence attributes of oral isolates of Candida spp. obtained from elderly healthy individuals. Mycopathologia 2008; 166: 209-17.

26. Khanpayeh E, Jafari AA, Tabatabaei Z. Comparison of salivary Candida profile in patients with fixed and removable orthodontic appliances therapy. Iran J Microbiol 2014; 6: 263-8.

27. Zheng $Y, L i Z, H e X$. Influence of fixed orthodontic appliances on the change in oral Candida strains among adolescents. J Dent Sci 2016; 11: 17-22.

28. Alexander SA. Effects of orthodontic attachments on the gingival health of permanent second molars. Am J Orthod Dentofacial Orthop 1991; 100: 337-40.

29. Addy M, Shaw WC, Hansford P, Hopkins M. The effect of orthodontic appliances on the distribution of Candida and plaque in adolescents. Br J Orthod 1982; 9: 158-63.

30. Odeh ND, Shehabi A, Bitar ZA, Omari IA, Badran S, Omiri AM, et al. Oral Candida colonization in patients with fixed orthodontic appliances: The importance of some nutritional and salivary factors. Afr J Microbiol Res 2011; 5: 2150-4.

31. Hibino K, Wong RW, Hägg U, Samaranayake LP. The effects of orthodontic appliances on Candida in the human mouth. Int J Clin Pediatr Dent 2009; 19: 301-8. 